\title{
KEPEMIMPINAN KEPALA SEKOLAH DALAM MENGEMBANGKAN BUDAYA AGAMA DI MTsN 01 OGAN ILIR
}

\author{
Moh. Fuadi \\ Sekolah Tinggi Ilmu Tarbiyah Raudhatul Ulum Sakatiga \\ Email: fuadi_moh@yahoo.co.id
}

\begin{abstract}
Abstrak
Kepala sekolah merupakan penanggung jawab tehadap pelaksanaan dan pengembangan pendidikan di MTsN 01 Ogan Ilir merupakan lembaga negeri yang mempuyai orientasi mengembangkan budaya agama dengan memperhatikan respon semua warga sekolah. Lembaga tersebut termasuk lembaga pendidikan yang perduli dalam pengembangan budaya agama.

Budaya agama di MTsN 01 Ogan Ilir sementara ini yang di gambarkan adalah, komunitas (warga) Sekolah yang belum mengamalkan ajaran dan nilai-nilai agama secara maksimal dalam kehidupan sehari-hari. Kehidupan di lingkungan sekolah belum memberikan corak kehidupan yang sesuai dengan ajaran Islam, Kepala Sekolah berusaha mengawal dan menghimbau semua warga sepakat untuk menciptakan budaya agama di Sekolah dan berusaha untuk melaksanakannya semaksimal mungkin. Dalam kehidupan sehari-hari belum semua warga mengamalkan nilai-nilai agama, sebagai budaya agama di sekolah seperti : (a) Membudayakan salam bagi warga / Komunitas Sekolah (b) Kegiatan Sholat berjamaah dzuhur belum maksimal dilaksanakan. (c) Berbusana Muslim belum sesuai denga harapan. (d) Kurang menyadari makna hidup sehat dan bersih lingkungan (e) Budaya Shadaqoh belum dapat diterapkan secara maksimal (f) Budaya sholat duha blm maksimal dilaksanakan ( $g$ ) Belum semua siswa bisa membaca Al-qur'an, baik secara murottal maupun mujawwad. (h) Berdo'a sebelum dan sesudah pelajaran belum maksimal dilaksanakan. (i) Minimnya kesadaran warga terhadap pelaksanaan Imtaq bersama.(j) Banyaknya siswa yang tidak mentaati peraturan dan tata tertib sekolah. (k) Menghargai dan menghormati orang lain masih perlu untuk ditingkatkan.
\end{abstract}

Kata Kunci: Kepemimpinan, Kepala Sekolah, Pengembangan Budaya Agama

\section{Pendahuluan}

Pendidikan merupakan salah satu investasi yang sangat berharga bagi Masyarakat. Pendidikan yang dapat menjanjikan terhadap Masyarakat berarti pendidikan yang dapat mengantarkan perubahan yang sangat berarti dalam Masyarakat tersebut. Selanjutnya, perubahan model pendidikan yang beraneka ragam dalam mewujudkan urgensinya tidak dapat dilepas pisahkan dengan tuntutan situasi dan kondisi Masyarakat.

Dewasa ini masalah moralitas muda-mudi, khususnya pelajar dan mahasiswa sudah menjadi problem umum yang merupakan persoalan yang belum ada jawabannya secara tuntas. Mahasiswa dan pelajar sekarang mudah terpengaruh oleh 
Kepemimpinan Kepala Sekolah Dalam Mengembangkan Budaya Agama Di Mtsn 01 Ogan Ilir

\section{Moh. Fuadi}

budaya asing, mudah terprovokasi, cepat marah, pergaulan bebas dengan lawan jenis, yang ditunjukkan dengan maraknya seks bebas yang terjadi banyak melibatkan mahasiswa dan pelajar, banyak dari mereka tidak lagi menaruh hormat terhadap guru-gurunya, bahkan tidak hormat terhadap orang tua. Hal ini merupakan gambaran anak bangsa yang mulai terancam keutuhan pribadinya.

Melihat kenyataan diatas, maka sangatlah beralasan apabila kemudian ada kritik dari masyarakat bahwa selama ini. Sekolah hanya menghasilkan lulusan yang hanya memiliki keahlian tertentu, sementara mereka tidak memiliki integritas kepribadian sebagai anggota keluarga, masyarakat, dan warga negara yang beragama. Kondisi demikian tentunya sangat berpengaruh pada sistim pendidikan di sekolah, terlebih di sekolah umum. Jika pengembangan intlektual yang tidak dibarengi dengan penanaman nilai-nilai Islam yang diwujudkan dalam pengembangan budaya agama disekolah, maka tujuan pendidikan nasional tidak akan tercapai dengan baik.

Pendidikan Agama khususnya Islam, sebenarnya memiliki kawasan yang begitu luas, dengan target obsesi agar melalui pendidikan ini para siswa mampu memahami, menghayati dan menerapkan ajaran-ajaran Islam yang termuat dalam kitab suci Al-qur'an dan Sunnah Rasul. Kedua sumber ajaran ini sebagaimana kita ketahui memuat segala aspek kehidupan, baik aspek ritual, intlektual, sosio maupun lainnya. Sasaran yang ingin dicapai dan dikembangkan meliputi aspek hati nurani agar memiliki kehalusan budi (Ahlakul karimah) daya nalar dan pikir agar anak cerdas dan memiliki keterampilan yang tinggi .

Dalam UU No. 20 / 2003 tentang Sisdiknas pasal 1 ayat 1 dinyatakan bahwa pendidikan adalah usaha sadar dan terencana untuk mewujudkan suasana belajar dan pembelajaran agar peserta didik secara aktif mengembangkan potensi dirinya untuk memiliki kekuatan spiritual keagamaan, pengendalian diri, kepribadian, kecerdasan, akhlak mulia serta keterampilan yang diperlukan untuk dirinya, masyarakat, Bangsa dan Negara. Selanjutnya pasal 1 ayat 2 dinyatakan bahwa pendidikan nasional adalah pendidikan yang berdasarkan pancasila dan UndangUndang Dasar Negara Republik Indonesia Tahun 1945 berakar pada Nilai-Nilai Agama, kebudayaan nasional Indonesia dan tanggap terhadap tuntutan perubahan zaman.

Pendidikan Agama Islam (PAI) baik pada jenjang pendidikan dasar maupun menengah antara lain bertujuan untuk mewujudkan manusia Indonesia yang taat beragama dan berakhlak mulia, yaitu manusia yang berpengetahuan, rajin beribadah, cerdas, produktif, jujur, adil, etis, berdisiplin, bertoleransi (tasamuh) menjaga keharmonisan, secara personal dan social serta Mengembangkan Budaya Agama dalam komunitas sekolah (Permen Diknas, No: 22 tanggal 23 Mei 2006 tentang Standar isi dalam standar kompetensi dan kompetensi dasar mata pelajaran PAI). Dengan demikian upaya pengembangan Pendidikan Agama sebagai budaya sekolah telah memperoleh legalitas yang kuat. 
Pengembangan Budaya Agama di Kabupaten Ogan Ilir melalui kegiatan imtaq bersama setiap hari jum'at di setiap jenjang pendidikan dan kegiatan keagamaan tidak tercantum dalam peraturan daerah, tetapi Kepala Daerah dalam setiap kegiatan senantiasa menghimbau agar Pengembangan Budaya Agama diamalkan di setiap instansi terkait dan menginternalisasikan nilai-nilai agama dan berprilaku akhlakul karimah dalam kehidupan sehari-hari. Himbauan ini mulai diindahkan sejak tahun 2006 hingga sekarang. Sebelumnya kegiatan (Imtaq) ini diistilahkan dengan Jum'at bersih.

Di MTsN 01 Ogan Ilir sangatlah penting untuk dikembangkan nilai-nilai agama sebagai budaya Agama di sekolah dengan tujuan untuk memupuk moral siswa-siswi kearah yang lebih baik dan mengajarkan siswa untuk selalu konsisten dengan ajaran dan nilai-nilai agama Islam yang telah tercantum dalam Al-Qur'an dan Al-hadits. Kepala Sekolah dalam kepemimpinannya selalu berusaha mengkaitkan pelajaran Pendidikan Agama Islam melalui pengembangan budaya Agama di sekolah dan sedapat mungkin bisa diterapkan dan diaplikasikan dalam kehidupan sehari-hari.

Pendidikan Agama sebagai salah satu kegiatan untuk membangun pondasi imtaq yang kokoh, ternyata belum dapat berjalan secara maksimal. Kurang berhasil pendidikan agama disekolah secara khusus dan masyarakat secara umum adalah masih lebarnya jurang pemisah antara pemahaman agama masyarakat belum dibarengi dengan prilaku agama yang diharapkan. Indikator yang sangat nyata adalah semakin banyaknya para pelajar yang terlibat dalam tindakan yang tidak diinginkan dan bertentangan dengan ajaran agama yang diajarkan.

Sementara sebagian masyarakat menganggap bahwa terjadinya kasus-kasus tersebut disebabkan karena kegagalan pendidikan agama Islam di sekolah. Kurang efektifnya pendidikan agama seperti yang berjalan saat ini, pada gilirannya akan menimbulkan kekhawatiran dari berbagai pihak terhadap mentalitas bangsa pada masa yang akan datang. Dengan demikian maka sekolah memang dihadapkan pada persoalan dilematis. Di satu sisi dituntut untuk mengembangkan Teknologi Informatika dengan segala konsekwensinya dalam menghadapi era globalisasi, namun di sisi lain sekolah harus memikul tanggung jawab terhadap dampak negatif dari kemajuan iptek modern yaitu dekadensi moral yang mengarah pada demoralisasi. Yang menjadi persoalan sekarang adalah bagaimana sekolah sebagai pendidik kedua anak bangsa dapat memerankan fungsi secara optimal dengan para lulusan yang beriman dan bertaqwa, memiliki kepribadian yang utuh dan memiliki keahlian yang matang dan profesionalisme. Jawaban-jawaban pertanyaan di atas adalah tantangan bagi sekolah untuk memberikan pencerahan spiritual dalam rangka membangun nurani bangsa.

Kepala Sekolah MTsN 01 Ogan Ilir sebagai orang yang bertanggung jawab terhadap pelaksanaan pendidikan, harus memiliki kesiapan dan kemampuan untuk membangkitkan semangat kerja secara kelompok atau individu. Seorang Kepala Sekolah juga harus mampu menciptakan suasana dan iklim yang kondusif, aman, 
Kepemimpinan Kepala Sekolah Dalam Mengembangkan Budaya Agama Di Mtsn 01 Ogan Ilir

Moh. Fuadi

nyaman, tenteram, menyenangkan, dan penuh semangat dalam bekerja sama, sehingga pendidikan dan pengajaran dapat berjalan tertib dan lancar. Untuk mencapai beberapa tujuan yang diharapkan oleh semua warga sekolah dan masyarakat maka, Kepala Sekolah hendaknya memiliki peran kepemimpinan pendidikan yang kuat dalam arti mampu untuk mempengaruhi, mengkoordinir dan menggerakkan semua warga untuk mencapai tujuan.

\section{Fokus Penelitian}

Berdasarkan fokus penelitian dan permasalahan yang sudah peneliti kemukakan, maka peniliti bisa memfokuskan penelitan ini pada: Kepemimpinan Kepala Sekolah dalam mengembangkan Budaya Agama di MTs N 01 Ogan Ilir. Fokus tersebut dapat dijabarkan sebagai berikut:

1. Apa saja nilai-nilai Agama yang dikembangkan di MTs N 01 Ogan Ilir?

2. Bagaimana Peran Kepemimpinan dan upaya Kepala Sekolah dalam mengembangkan nilai-nilai Agama di MTs N 01 Ogan Ilir?

3. Bagaimana respon dan dukungan warga sekolah terhadap upaya Pengembangan nilai-nilai Agama di MTs N 01 Ogan ilir?

\section{Tujuan Penelitian}

Dari konteks penelitian yang sudah peneliti paparkan, maka penelitian ini bertujuan untuk:

1. Mendiskripsikan apa saja nilai-nilai Agama yang dikembangkan di MTsN 01 Ogan Ilir

2. Mendeskripsikan bagaimana peran kepemimpinan dan upaya Kepala Sekolah dalam mengembangkan nilai-nilai Agama di MTsN 01 Ogan Ilir

3. Mendiskripsikan bagaimana respon dan dukungan warga sekolah terhadap upaya pengembangan nilai-nilai Agama di Sekolah.

\section{Manfaat Penelitian}

Hasil penelitian ini diharapkan dapat memberikan sumbangsih pemikiran yang positif dan manfaat yang mendalam tentang Kepemimpinan Kepala Sekolah dalam Mengembangkan Budaya Agama. Idealnya manfaat Penelitian ini secara praktis dan teoritis berarti bagi beberapa kepentingan, antara lain :

1. Secara teoritis

Bagi peneliti selanjutnya dapat dijadikan panduan untuk mengadakan penelitian selanjutnya, terlebih dalam upaya untuk mengembangkan dan meningkatkan Budaya Agama di Sekolah.

2. Secara Praktis

a. Dapat memberikan informasi kepada Sekolah atau Lembaga tentang pentingnya peran kepemimpinan Kepala Sekolah terutama dalam mengembangkan Budaya Agama di komunitas Sekolah. 
P-ISSN : 2541-3686

b. Bagi MTsN 01 Ogan Ilir dapat mempertahankan apa yang sudah ada dan selalu berusaha untuk menigkatkan Budaya agama yang sudah ada kearah yang lebih baik dan diaplikasikan dimanapun dan kapanpun, bukan hanya di lingkungan Sekolah saja. Sebagai perubahan tingkah laku yang konstruktif, Juga sebagai bahan masukan ( input) bahwa internalisasi nilai-nilai Ajaran Agama perlu ditangani secara khusus di lingkungan Sekolah, sehingga tidak ada kesenjangan antara nilai secara kongnitif dan prilaku moral secara afektif psikomotorik.

c. Bagi seluruh pemerhati pendidikan, Masyarakat, dan orang tua siswa di lingkungan MTsN 01 Ogan Ilir diharapkan sebagai bahan masukan tentang sejauh mana pemahaman, penghayatan dan pengalaman nilai-nilai Islam dalam kehidupan sehari-hari oleh putra-putrinya sehingga orang tua bisa menindak lanjuti apabila ada kesenjangan antara harapan orang tua dengan realita yang ditunjukkan oleh prilaku putra-putrinya. Dan dapat bekerja sama dan mendukung pengembangan Budaya Agama di Sekolah.

d. Sebagai bahan informasi untuk mengevaluasi sistem pengajaran Pendidikan Agama Islam yang sedang dan yang akan berlangsung, sehingga tidak hanya sekedar transfer ilmu pengetahuan, tetapi merupakan upaya serius untuk membentuk pribadi muslim yang kaffah (sempurna) sehingga perlu strategi pembelajaran dan mengintegrasikannya dengan pelajaran yang lain.

e. Bagi Siswa MTsN 01 Ogan Ilir, diharapkan bisa mengamalkan nilai-nilai ajaran agama dalam kehidupan sehari-hari, baik di lingkungan Sekolah atau di Masyarakat.

\section{Kajian Pustaka}

\section{Pengertian Kepemimpinan}

Kata "Pemimpin" mempunyai arti memberikan bimbingan, menuntun, mengarahkan dan berjalan didepan (precede). Pemimpin berprilaku untuk membantu organisasi dengan kemampuan maksimal untuk mencapai tujuan. Manusia secara individual juga komunal merupakan sosok yang diciptakan (mahluk) untuk mengabdi kepada tuhan, dengan menjadi hamba, karyawan atau anggota masyarakat, bersama mahluk-mahluk tuhan yang lain. Namun diantara mahluk di bumi hanya manusia yang telah sah mendapat mandat untuk menjadi khalifah, pengelola juga menjadi pemimpin di bumi. Jadi manusia secara Individual, juga komunal, mempunyai potensi ganda yaitu menjadi pemimpin juga menjadi rakyat, ketua, manajer, karyawan, abdun atau hamba.

Kehadiran pemimpin merupakan salah satu yang sangat esensial mengingat pemimpin merupakan motor penggerak bagi sumber daya yang ada dalam suatu lembaga. Oleh karena itu kepemimpinan disebut sebagai fungsi organic dalam proses manajemen. Terkait dengan kepemimpinan, sekolah atau suatu lembaga, maka peran seorang pemimpin menjadi bagian penting dalam keefektifan lembaga dalam mencapai tujuan yang diharapkan. Kepemimpinan dalam Islam adalah prilaku interaktif yang mampu mempengaruhi individu-individu untuk 
Kepemimpinan Kepala Sekolah Dalam Mengembangkan Budaya Agama Di Mtsn 01 Ogan Ilir

Moh. Fuadi

melaksanakan tugasnya dalam rangka memberikan arahan, petunjuk yang lebih baik dalam mencapai tujuan yang telah ditetapkan, mengembangkan, memegang teguh dan menjaga kepercayaan yang dipercayakan kepadanya.

Peran kepala sekolah sebagai seorang pemimpin harus mampu meningkatkan peran strategis dan tehnis dalam menigkatkan kualitas lembaga yang dipimpinnya. Kepemimpinan kepala sekolah sebagai agen perubahan dalam meningkatkan kualitas keagamaan sangat penting juga untuk diperhatikan, karena dengan dasar agama siswa mampu menjalankan aktifitas belajar dan bergaul di lingkungan masyarakat dengan didasari oleh nilai-nilai agama. Untuk itu hal budaya agama perlu ditanamkan kepada siswa melalui pengembangan budaya agama di lingkungan Sekolah. Hal ini menuntut Kepala Sekolah untuk mampu mengelola dan menciptakan iklim yang baik dalam komunitas sekolah, hal tersebut dimaksudkan agar semua komponen yang ada di Sekolah dapat memerankan diri secara bersamasama untuk mencapai sasaran dan tujuan sekolah.

\section{Pengembangan Budaya Agama di Komunitas Sekolah}

Muhaimin dalam bukunya Rekonstruksi Pendidikan Agama Islam menjelaskan bahwa pendidikan agama islam pada dasarnya harus menyentuh 3 (tiga) aspek secara terpadu, yaitu: (1) Knowing, yakni agar peserta didik dapat mengetahui dan memahami ajaran dan nilai agama, (2) Doing yakni agar peserta didik dapat memperaktikkan ajaran-ajaran dan nilai-nilai agama, (3), Being yakni agar peserta didik dapat menjalani hidup sesuai dengan ajaran dan nilai-nilai agama.

Istilah nilai keberagamaan merupakan istilah yang tidak mudah untuk diberikan batasan secara pasti. Ini disebabkan karena nilai merupakan sebuah realitas yang abstrak. Peran pendidikan agama Islam dalam rangka pembinaan sikap religious dikomunitas sekolah dapat dipahami sebagai sikap dan tindakan yang didasari oleh kepercayaan terhadap nilai-nilai kebenaran yang diyakininya. Agama dalam kehidupan beragama merupakan unsur yang tidak dapat dipisahkan dari kehidupan dan sistem budaya umat beragama.

\section{Kebudayaan dan Agama}

Kata Kebudayaan berasal dari bahasa Sansekerta yaitu Budhayah, bentuk jamak dari kata Buddhi yang berarti budi atau akal. Ada juga yang mengatakan bahwa kata Budaya itu sebagai perkembangan dari kata majemuk budi daya yang berarti kemampuan dari budi atau akal (Koentjaraningrat, 1976), sementara Djojodiguna, 1985 membedakan antara Budaya dan kebudayaan. Budaya adalah daya dari budi yang berupa cipta, rasa dan karsa. Sedangkan kebudayaan adalah hasil dari cipta, karsa, dan rasa. 
Dalam Buku Pendidikan Agama Islam, yang disusun oleh Tim Dosen PAI Universitas Brawijaya Malang memberikan definisi tentang kebudayaan sebagai berikut:

- Kebudayaan adalah: manifestasi dari perwujudan aktifitas manusia sebagai upaya untuk memenuhi kebutuhan hidupnya, ia merupakan perwujudan dari ide, pemikiran, gagasan, nilai-nilai, norma dalam bentuk tindakan dan karya. Oleh karena itu, kebudayaan adalah suatu yang spesifik manusiawi (Abdul Munir Mulkhan 1996).

- Kebudayaan adalah: keseluruhan sistim gagasan, tindakan, dan hasil cipta, karsa, dan rasa manusia untuk memenuhi kebutuhan kehidupannya dengan cara belajar, yang semuanya tersusun dalam kehidupan bermasyarakat.

Definisi yang lainnya dikemukakan oleh Koentjoroningrat bahwa: Kebudayaan adalah keseluruhan dari kelakuan dan hasil kelakuan manusia yang teratur oleh tata kelakuan yang harus didapatinya dengan belajar dan yang semuanya tersusun dalam kehidupan masyarakat. Koentjoroningrat mengemukakan adanya 3 wujud dari kebudayaan yaitu :

1. Wujud kebudayaan sebagai suatu yang kompleks.

2. Wujud kebudayaan sebagai suatu yang kompleks aktifitas kelakuan berpola dari manusia dalam masyarakat.

3. Wujud kebudayaan sebagai benda-benda hasil karya manusia. Dalam praktiknya kebudayaan tersebut tidak terpisah antara yang satu dengan yang lainnya.

Sedangkan Agama, berasal dari bahasa sansekrta, masuk dalam perbendaharaan bahasa melayu (Nusantara) dibawa oleh agama hindu dan budha. Mengenai pengertian dasarnya terdapat perbedaan pendapat, ada yang menyatakan bahwa Agama berasal dari kata " $a$ " yang berarti tidak, dan gama yang berarti kacau balau atau kocar- kacir. Jadi kata agama berarti tidak kacau, tidak kocar-kacir, dan berarti teratur. Dengan pengertian dasar demikian maka istilah agama merupakan suatu kepercayaan yang mendatangkan kehidupan yang teratur, tidak kacau balau, serta mendatangkan kesejahtraan dan keselamatan bagi hidup manusia.

\section{Konsep Budaya Agama}

Keberagamaan seseorang bisa diwujudkan dalam berbagai sisi kehidupan, Aktifitas agama bukan saja terjadi ketika seseorang melakukan prilaku ritual ( beribadah), tetapi juga ketika melakukan kegiatan lain yang didorong oleh kekuatan supranatural. Bukan hanya berkaitan dengan aktifitas yang tampak dan dapat dilihat dengan mata, tetapi juga aktifitas yang tidak tampak dan terjadi dalam hati seseorang. Karena itu keberagaman seseorang akan meliputi berbagai macam sisi atau dimensi.

Konsep Islam tentang budaya agama dapat dipahami dari doktrin keagamaan. Dalam Islam seseorang diperintahkan untuk beragama secara kaffah, hal ini dijelaskan dalam Al-qur'an surat Al baqarah ayat 208, 


\title{
Kepemimpinan Kepala Sekolah Dalam Mengembangkan Budaya Agama Di
} Mtsn 01 Ogan Ilir

Moh. Fuadi

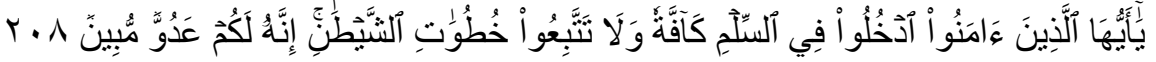 \\ Artinya: Hai orang-orang yang beriman, masuklah kamu ke dalam Islam \\ keseluruhan, dan janganlah kamu turut langkah-langkah syaitan. \\ Sesungguhnya syaitan itu musuh yang nyata bagimu.
}

Setiap muslim baik dalam berfikir, bersikap maupun bertindak, diperintahkan untuk selalu sesuai dengan ajaran Islam. Dalam melakukan aktifitas ekonomi, sosial, politik atau aktifitas lainnya seorang muslim diperintahkan untuk melakukannya dalam rangka beribadah kepada Allah, dimanapun dan dalam keadaan apapun setiap muslim hendaknya berpedoman pada Al-qur'an dan as-sunnah.

Esensi Islam adalah tauhid dan pengesaan. Tauhid adalah tindakan yang menegaskan Allah itu Esa, pencipta yang mutlak dan transenden, penguasa segala yang ada, tidak satupun perintah dalam islam yang bisa lepas dari tauhid. Ismail $\mathrm{R}$ Faruqi menyatakan bahwa seluruh agama mewajibkan untuk menyembah Tuhan, untuk mematuhi perintah-perintah-Nya dan menjauhi larangan-larangan-Nya.. Dapat disimpulkan bahwa tauhid adalah intisari islam dan suatu tindakan tidak dapat disebut sebagai bernilai islam tanpa dilandasi oleh kepercayaan kepada Allah.

Muhaimin, dalam bukunya Rekonstruksi Pendidikan Islam menjelaskan bahwa: Strategi pengembangan budaya agama di Sekolah meminjam teori Koentjaraningrat (1974) tentang wujud kebudayaan, meniscayakan adanya upaya pengembangan dalam tiga tataran, yaitu tataran nilai yang dianut, tataran praktik keseharian, dan symbol-simbol budaya.

- Dalam tataran nilai yang dianut perlu dirumuskan secara bersama nilai-nilai agama yang disepakati dan perlu di kembangkan di Sekolah, untuk selanjutnya dibangun komitmen dan loyalitas bersama diantara semua warga sekolah terhadap nilai-nilai yang disepakati. Seperti hubungan manusia atau warga sekolah dengan Allah (hubungan vertical) dan yang horizontal berwujud hubungan manusia atau warga sekolah dengan sesamanya, dan hubungan mereka dengan lingkungan dan alam sekitarnya.

- Dalam tataran praktik keseharian, nilai-nilai keagamaan yang disepakati tersebut diwujudkan dalam bentuk sikap dan prilaku keseharian oleh warga sekolah. Proses pengembangan tersebut dapat dilakukan dengan tiga cara, Pertama, sosialisasi nilai-nilai agama yang disepakati sebagai sikap dan prilaku ideal yang ingin dicapai pada masa mendatang di sekolah. Kedua, penetapan action plan mingguan atau bulanan sebagai tahanan dan langkah sistematis yang akan dilakukan oleh semua warga disekolah dalam melaksanakan nilai-nialai agama yang telah disepakati tersebut. Ketiga, Pemberian penghargaan terhadap prestasi warga sekolah, seperti guru, tenaga kependidikan, dan peserta didik sebagai usaha pembiasaan ( habit formation ) yang menjunjung sikap dan prilaku komitmen dan loyal terhadap ajaran dan nilai-nilai agama yang disepakati. 
P-ISSN : 2541-3686

- Dalam tataran simbol-simbol budaya, Pengembangan yang perlu dilakukan adalah mengganti symbol-simbol budaya yang kurang sejalan dengan ajaran dan nilainilai agama dengan symbol budaya yang agamis. Perubahan symbol dapat dilakukan dengan mengubah model berpakaian dengan prinsip menutup aurat , pemasangan hasil karya peserta didik, foto-foto dan moto yang mengandung pesan-pesan nilai-nilai keagamaan dan lain-lain.

\section{Sikap Religius Sebagai Orientasi Moral}

Moral adalah keterkaitan spiritual pada norma-norma yang telah diterapkan, baik yang bersumber pada ajaran agama, budaya masyarakat atau berasal dari berfikir secara ilmiah. Keterkaitan spiritual tersebut akan mempengaruhi keterkaitan sikapnya terhadap nilai-nilai kehidupan yang akan menjadi pijakan utama untuk menetapkan suatu pilihan, pengembangan perasaan dan dalam menentukan suatu tindakan.

Keterkaitan norma-norma religious akan membentuk sikap dan prilaku dalam menyikapi segala persoalan. Moral yang dikembangkan atas pijakan agama, maka pijakan-pijakan moralnya akan lebih berorientasi pada kewajiban-kewajiban beragama. Sedangkan sumber-sumber moral hanya dibenarkan manakala dianggap sebagai ajaran agama.

Segala tidakan moral yang didasari ketentuan agama akan muncul karena rasa tanggung jawab kepada tuhan. Segala tindakan yang akan diambil dirasakan sebagai keharusan Rabbani. Sedangkan motif memilih tindakan semata-mata karena ingi mendapatkan keridhoan dari Allah SWT.

Zaim El-Mubarok, dalam bukunya menjelaskan bahwa: Ajaran Moral adalah Ajaran tentang bagaimana manusia harus hidup dan berbuat agar menjadi manusia yang baik. Sedangkan Moral adalah: Sistem nilai atau consensus Sosial tentang motivasi, prilaku dan perbuatan tertentu dinilai baik atau buruk.

Sikap budaya agama yang terbentuk dari keterikatan yang kuat pada normanorma yang diterapkan oleh agama akan menjadikan seseorang dapat mengukur kebenaran suatu hal dari sudut pandang agama. Sebagai orientasi moral, sikap budaya agama (Religius) bermakna spiritual pada norma-norma ajaran agama yang akan menjadi acuan pertama ukuran-ukuran moral.

\section{Sikap Religious Sebagai Internalisasi Nilai Agama}

Suasana keagamaan di lingkungan sekolah dengan berbagai bentuknya, sangat penting bagi proses penanaman nilai agama pada siswa. Proses penanaman nilai agama islam pada siswa disekolah akan menjadi lebih intensif dengan suasana kehidupan sekolah yang islami, baik yang Nampak dalam kegiatan, sikap maupun prilaku, pembiasaan, penghayatan, dan pendalaman.

Penggunaan metode \& Pendekatan dalam penanaman nilai, adalah suatu yang member penekanan pada penanaman nilai - nilai social dalam diri siswa. Menurut et al. (1976), tujuannya adalah: diterimanya nilai-nilai agama oleh siswa dan 
Kepemimpinan Kepala Sekolah Dalam Mengembangkan Budaya Agama Di Mtsn 01 Ogan Ilir

\section{Moh. Fuadi}

berubahnya nilai-nilai tingkah laku siswa yang tidak sesuai kearah yang lebih agamis.

Dalam penyajian bahan pelajaran bagi setiap mata pelajaran yang memungkinkan, akan menambah proses internalisasi (Penanaman) nilai agama yang relevan dari setiap mata pelajaran yang disampaikan oleh guru di sekolah. Dan kualifikasi Guru yaitu harus beragama Islam dan berakhlak mulia akan semakin mendukung terjadinya proses internalisasi nilai agama melalui pendekatan kharismatik. Dengan pendekatan ini siswa dihadapkan dengan kepribadian orangorang (guru-guru) yang memiliki keteladanan yang dapat diandalkan untuk selalu dilihat dan diamati hingga tumbuh kesadaran untuk menerima nilai-nilai yang ditampilkan oleh para pendidik (guru) yang baik dan benar.

Internalisasi nilai agama adalah suatu proses memasukkan nilai agama secara penuh kedalaman hati, sehingga ruh dan jiwa berdasarkan ajaran agama. Internalisasi nilai agama terjadi melalui pemahaman ajaran agama secara utuh, dan diteruskan dengan kesadaran akan pentingnya ajaran agama, serta ditemukan posibilitas untuk merealisasikannya dalam kehidupan nyata. Dari segi Isi, agama terdiri dari seperangkat ajaran yang merupakan seperangkat nilai-nilai kehidupan yang harus dijadikan barometer para pemeluknya dalam menentukan pilihan tindakan dalam kehidupannya. Nilai-nilai ini secara popular disebut dengan nilai agama. Oleh sebab itu nilai-nilai agama merupakan seperangkat standar kebenaran dan kebaikan.

\section{Budaya Agama Sebagai Etos Kerja dan Keterampilan Sosial}

Seperangkat ajaran dalam agama bertujuan membimbing, mendorong untuk berbuat dan memilih tindakan tertentu. Lebih penting dari itu agama memberi makna terhadap segala tindakan yang dilakukan. Disinilah agama berperan sebagai sumber etos kerja, bagi seseorang pemeluk agama, etos kerja muncul dari golongan sikap yang terbentuk oleh nilai-nilai agama.

Kesanggupan seseorang menampilkan nilai-nilai agama dalam kehidupannya sebagai keterampilan sosial sangat tergantung pada kuat lemahnya pemahaman agama yang ada dalam jiwanya. Pemahaman agama tersebut di tampilkan dalam bentuk tindakan dan prilaku terhadap lingkungan selaras dengan apa yang diperintahkan oleh ajaran agama. Bagi yang memiliki budaya agama, secara konsekwen tampil dalam bentuk tindakan-tindakan yang mendukung terbentuknya tatanan sosial yang harmonis. Ada beberapa hal yang menjadi indicator budaya agama seseorang yaitu : (1) komitmen terhadap larangan dan perintah agama. (2) Bersemangat mengkaji ajaran agama (3) aktif dalam kegiatan agama (4) Menghargai simbol-simbol agama (5) Akrab dengan kitab suci sebagai sumber ajaran agama (6) Menggunakan pendekatan agama dalam menentukan pilihan (7) Ajaran agama di jadikan sebagai sumber untuk mengembangkan ide. Ketujuh sikap diatas dapat dijadikan sebagai acuan untuk mengukur berhasil atau tidaknya pelaksanaan pendidikan Agama Islam di Sekolah, karena tujuan utama pendidikan Agama 
P-ISSN : 2541-3686

adalah membina kepribadian agar menjadi orang yang taat melaksanakan ajaran Agama.

\section{Terbentuknya Budaya Agama Di Sekolah}

Kepala Sekolah dalam memimpin lembaga dan mengembangkan budaya Agama, dapat mengacu kepada beberapa model yang ditawarkan. Model adalah sesuatu yang dianggap benar, tetapi bersifat kondisional. Karena itu penciptaan suasana religius sangat dipengaruhi oleh situasi dan kondisi tempat model itu akan diterapkan beserta penerapan nilai-nilai yang mendasarinya. Menurut Muhaimin, ada 4 model pengembangan budaya agama dikomunitas sekolah yaitu

a. Model Struktural.

Pengembangan budaya agama dengan model ini disemangati oleh adanya peraturan-peraturan, pembangunan kesan, baik dari dunia luar maupun dari kepemimpinan atau kebijakan suatu lembaga pendidikan atau suatu organisasi. Model ini biasanya bersifat tof down yakni kegiatan keagamaan yang dibuat atas prakarsa atau instruksi dari pejabat atau pimpinan atasan.

b. Model Formal.

Pengembangan budaya agama model ini didasari atas pemahaman bahwa pendidikan agama adalah upaya manusia untuk mengembangkan dan mengerjakan masalah-masalah kehidupan akhirat atau kehidupan rohani saja, sehingga pendidikan agama dihadapkan dengan pendidikan non keagamaan, pendidikan keislaman dengan pendididkan non keislaman, pendidikan Kristen dengan non Kristen demikian seterusnya.

Model pengembangan budaya agama ini, lebih berimplikasi terhadap pengembangan pendidikan agama yang lebih berorientasi pada keakhiratan, sedangkan masalah dunia dianggap tidak penting, serta menekankan pada pendalaman ilmu-ilmu keagamaan yang merupakan jalan pintas untuk menuju kebahagiaan akhirat. Sementara sains (ilmu-ilmu pengetahuan) dianggap terpisah dari ilmu-ilmu agama.

c. Model Mekanik.

Pengembangan budaya agama dengan model ini adalah yang didasari oleh pemahaman bahwa kehidupan terdiri dari beberapa aspek, dan pendidikan dipandang sebagai penanaman dan pengembangan seperangkat nilai kehidupan yang masing-masing bergerak dan menjalankan fungsinya. Masing-masing gerak bagaikan sebuah mesin yang terdiri atas beberapa komponen atau elemen-elemen, yang masing-masing menjalankan fungsinya sendiri-sendiri, dan antara satu dengan yang lainnya bisa saling berkonsultasi atau tidak.

Model mekanik tersebut berimplikasi terhadap pengembangan pendidikan agama islam yang lebih menonjolkan fungsi moral dan spiritual atau dimensi afektif daripada kognitif dan psikomotorik. Artinya dimensi Kognitif dan psikomotorik dapat diarahkan untuk pembinaan afektif (moral dan spiritual), yang berbeda 
Kepemimpinan Kepala Sekolah Dalam Mengembangkan Budaya Agama Di Mtsn 01 Ogan Ilir

\section{Moh. Fuadi}

dengan pelajaran lainnya kegiatan dan kajian-kajian keagamaan hanya untuk pendalaman agama dan kegiatan spiritual keagamaan)

d. Model Organik.

Pengembangan budaya agama dengan model ini, yaitu pengembangan budaya agama yang disemangati oleh adanya pandangan bahwa pendidikan agama adalah kesatuan atau sebagai system (yang terdiri atas komponen-komponen yang rumit) yang berusaha mengembangkan pandangan atau semangat hidup agamis, yang dimanifestasikan dalam sikap hidup dan keterampilan hidup yang religious.

Model pengembangan budaya agama organic tersebut berimplikasi terhadap pengembangan pendidikan agama yang dibangun dari fundamental values (lingkungan) yang tertuang dan terkandung dalam Al-qur'an dan Al-sunnah shahihah sebagai sumber pokok kemudian bersedia mau menerima konstribusi pemikiran dari para ahli serta mempertimbangkan konteks historisnya. Karena itu, nilai ahli Ilahi/ agama / wahyu didudukan sebagai sumber konsultasi yang bijak.

\section{Simpulan}

Berdasarkan fokus penelitian yaitu kepemimpinan kepala sekolah dalam mengembangkan budaya agama di MTsN 01 Ogan Ilir dengan fokus penelitian yang meliputi : (a) nilai-nilai Agama yang dikembangkan di MTsN 01 Ogan Ilir (b) peran kepemimpinan dan upaya kepala sekolah dalam mewujudkan dan mengembangkan nilai-nilai Agama di MTsN 01 Ogan Ilir, dan (c) respon warga sekolah terhadap upaya pengembangan nilai-nilai agama di MTsN 01 Ogan Ilir.

Dengan demikian berdasarkan paparan data, hasil analisis temuan penelitian dan pembahasan dapat diambil beberapa kesimpulan sebagai berikut:

1. Nilai-Nilai Agama yang Dikembangkan di MTsN 01 Ogan Ilir

Nilai-nilai agama yang dikembangkan di MTsN 01 Ogan Ilir dapat dilihat dari 3 (tiga) aspek yaitu : Pertama: Dalam UU No. 20 / 2003 Tentang Sisdiknas pasal 1 ayat 1 dinyatakan bahwa pendidikan adalah usaha sadar dan terencana untuk mewujudkan suasana belajar dan pembelajaran agar peserta didik secara aktif mengembangkan dirinya untuk memiliki kekuatan spiritual, pengendalian diri, kecerdasan, akhlak mulia serta keterampilan yang diperlukan untuk dirinya, masyarakat bangsa dan Negara. Selanjutnya pasal 1 ayat 2 dinyatakan bahwa pendidikan nasional adalah pendidikan yang berdasarkan Pancasila dan UndangUndang Dasar Negara Republik Indonesia Tahun 1945 berakar pada Nilai-Nilai Agama, kebudayaan nasional Indonesia dan tanggap terhadap tuntutan zaman.

Nilai-nilai Agama yang dikembangkan di sekolah juga berakar pada nilainilai agama yang yang ada di masyarakat Ogan Ilir. Mayoritas warga dan masyarakat Ogan Ilir yang beragama Islam dan adanya warisan nilai-nilai budaya Islam yang pernah diterapkan dan dikembangkan di pemerintah daerah dari pemerintahan yang pertama yaitu Lalu Wirentanus, sejak tahun 1961 selalu menghimbau masyarakat Ogan Ilir untuk membudayakan nilai-nilai agama dan 
P-ISSN : 2541-3686

berprilaku akhlakul karimah dalam kehidupan sehari-hari. Himbauan ini selalu diindahkan dan diterapkan sampai sekarang.

Kedua: nilai-nilai Agama yang dikembangkan dan dijadikan budaya dalam kehidupan sehari-hari yang dikembangkan di MTsN 01 Ogan Ilir adalah:

a. Nilai beriman dan bertaqwa.

b. Nilai amal sholeh

c. Nilai berdisiplin.

d. Nilai kekompakan dan kebersamaan.

e. Nilai demokrasi.

f. Nilai menghargai waktu.

g. Nilai keindahan dan kerindangan.

h. Nilai menghormati dan sopan santun.

i. Nilai hidup cermat dan nilai bersyukur.

Ketiga: berkaitan dengan nilai-nilai agama yang dikembangkan di MTsN 01 Ogan Ilir terdapat simbol-simbol yang di dalamnya mengandung nilai-nilai agama yang dikembangkan di sekolah yaitu:

a. Waktu ibarat pedang, jika tidak engkau manfaatkan maka ia akan membunuhmu.

b. Kebersihan sebagian daripada iman.

c. Bersatu kita teguh, bercerai kita runtuh.

d. Barang siapa yang menghendaki dunia hendaklah dengan ilmu, barang siapa yang menghendaki akirat maka hendaklah dengan ilmu, dan barang siapa yang menghendaki keduanya hendaklah pula dengan ilmu.

e. Sesungguhnya Allah tidak memandang seseorang dari kecantikan parasnya, akan tetapi Allah memandang dari ketaqwaan seseorang kepada-Nya.

f. Allah itu maha indah, Dia mencintai keindahan.

2. Peran kepemimpinan dan upaya kepala sekolah dalam mewujudkan dan mengembangkan nilai-nilai budaya agama di MTsN 01 Ogan Ilir

Kepala Sekolah MTsN 01 Ogan Ilir dalam membuat perencanaan, membuat strategi, dan pemecahan masalah, melakukan inovasi serta membuat konsep-konsep baru. Memiliki konsep budaya agama yang sudah baik, karena dilihat dari kemampuannya merencanakan kegiatan budaya agama dengan semua warga sekolah dan masyarakat di sekitarnya. Adapun bentuk upaya kepala sekolah dalam mewujudkan nilai-nilai agama di sekolah yaitu:

a. Mengadakan kegiatan imtaq bersama setiap hari Jum'at.

b. Membudayakan salam pada semua warga sekolah.

c. Membudayakan berbusana islami kesekolah. 
Kepemimpinan Kepala Sekolah Dalam Mengembangkan Budaya Agama Di Mtsn 01 Ogan Ilir

\section{Moh. Fuadi}

d. Menjadikan bahasa arab dan akidah akhlak sebagai muatan lokal.

e. Mengumandangkan adzan dzuhur dari pengurus osis atau remaja musholla secara bergiliran.

f. Mengadakan sholat dzuhur berjama'ah 2 gelombang bagi guru yang tidak ada jam mengajar dan bagi siswa sesuai dengan jadwal dari Pembina imtaq.

g. Mengadakan lomba-lomba kegiatan keagamaan setelah semester ( dikondisikan)

h. Peringatan hari besar Islam (PHBI)

i. Memberikan izin menggunakan fasilitas tempat ibadah (mushalla) kepada warga sebagai tempat ta'lim.

j. Siraman rohani bagi darmawanita yang disampaikan oleh kepala sekolah atau guru-guru pendidikan agama Islam.

k. Mengadakan do'a bersama menjelang ujian nasional \& sekolah bersama siswasiswi kelas IX dengan mengundang komite dan orang tua wali.

1. Mengadakan sujud syukur bersama setelah menerima pengumuman hasil ujian nasional ataupun Sekolah.

m. Membudayakan infaq dan shadaqah bagi guru dan siswa.

3. Respon warga sekolah terhadap pengembangan nilai-nilai agama di MTsN 01 Ogan Ilir.

Warga sekolah secara umum sudah menerima secara utuh tentang pentingnya nilai-nilai agama dikembangkan sebagai budaya agama di komunitas warga sekolah, karena manfa'atnya sudah mulai dirasakan dalam setiap lini pergaulan antar warga sekolah. Secara langsung maupun tidak langsung yang paling merasakan pentingnya budaya agama adalah para wali murid yang memiliki putra/i yang mengamalkan budaya agama dirumahnya. Respon warga sekolah terhadap upaya pengembangan budaya agama di MTsN 01 Ogan Ilir sudah mendapat dukungan dari semua warga sekolah. 


\section{DAFTAR PUSTAKA}

Abdullah, M Yatimin, 2007. Studi Akhlak dalam Perspektif Al-Qur'an, Jakarta: Amzah. Ancok, Djamaludin. 1995. Psikologi Islami, Solusi Islam atas atas Problem-problem Psikologi, cet. Ke II, Yogyakarta : Pustaka Pelajar.

Agustian, Ary Ginanjar. 2003. Rahasia Sukses Membangkitkan ESQ Power, Jakarta : ARGA

Alim, Muhammad , 2006. Pendidikan Agama Islam: Upaya Pembentukan Pemikiran dan Keppribadian Muslim, Bandung: PT Remaja Rosda Karya.

Alwi, Haddad, 2009. Uswatun Hasanah: (Hidup Mulia Bersama Rasulullah, Meneladani Rasul Meraih Cinta Allah) Jakarta : Hikmah PT Mizan Publika.

Al-Qur'an Tarjamah, 2005. Departemen Agama RI. Jumaanatul 'Aliy J.Art.

Aravik, Havis, Pengantar Studi Islam, Palembang, Rafah Press, 2018.

Asrori, Muhammad, 2008. Dinamika Pendidikan Islam di Indonesia, Jurnal el-harokah. Malang: UIN Press

Azra, Azzumardi. 2000. Pendidikan Islam Tradisi dan Modernisasi Menuju Milenium Baru. Ciputat : Logo Wacana Ilmu

Bernnis, warrant and Nanus, Burt. 1990. Kepemimpinan Strategi dalam mengemban tanggung jawab, Alih bahasa, Victor Purba. Jakarta: Air Langga.

Baharuddin, 2008. Sosiologi dan Pendidikan. Yogyakarta : Genta Press.

Burhanudin, 1994, Analisis Administrasi Manajemen dan Kepemimpinan Pendidikan, Jakarta: Bumi Aksara

Bafadal ,Ibrahim. 2003. Manajemen Mutu Sekolah Dasar dari Sentralisasi Menuju Desentralisasi. Jakarta: Bumi Aksara

Binti Wakhidati, 2002. Internalisasi dan Aktualisasi Nilai Ibadah Shalat Wajib Di SLTP Muhammadiyah Malang. Tesis Program Pascasarjana UMM Malang.

Depdiknas, 2007. Pemberdayaan Sekolah Berwawasan Imtaq. Dirjen Dikdasmen Kegiatan Pendidikan Agama dan Akhlak Mulia. Jakarta.

El-Mubarok, Zaim, 2008. Membumikan Pendidikan Nilai Mengumpulkan yang Terserak, Menyambung yang Terputus Dan Menyatukan Yang Tercerai. Bandung: Alfabeta.

Faisal, Sanapiah. 2008. format-format Penelitian Sosial. Jakarta : Raja Grapindo Persada.

Hendiyat, Sutopo. 1984. Kepemimpinan dan supervise Pendidikan. Jakarta: Bumi Aksara. 
Kepemimpinan Kepala Sekolah Dalam Mengembangkan Budaya Agama Di Mtsn 01 Ogan Ilir

Moh. Fuadi

Hoy. dan Miskel. 1987. Educationl Administration. New York: Random House.

Hidayat, M Human. 2007. (Mahasiswa PPs UIN Malang) Kepemimpinan Pengembangan Organisasi Team Building \& Prilaku Inovatif, Malang UIN Press.

Indrawijaya, 2002. Perubahan dan Pengembangan Organisasi. Bandung: Sinar baru.

Indrafachrudi, Soekarno. 2006. Bagaimana memimpin sekolah yang efektif. Bogor : Ghalia Indonesia.

Irmin, Sujitno. dan Abdul Rochim. 2008. Bekal Minimal Seorang Pemimpin. ISBN, Selaras

Imam, Mujiono. 2002 Kepemimpinan E Keorganisasian Yogyakarta UII Press

Kasiram , Moh. 2008. Metodologi Penelitian Kualitatif-kuantitatif. Malang : UIN Press

Kossen, Stan. 1993. Aspek Manusiawi Dalam Organisasi. Jakarta: Erlangga

Madjid, Nurcholish. 2000. Masyarakat Religius, Membumikan Nilai-Nilai Islam Dalam Kehidupan Masyarakat. Jakarta : Paramadina

Miles Matthew \& A. Michael Huberman 1992, Analisis Data Kualitatif Jakarta: Universitas Indonesia

Meleong, Lexi, J 1997, Metodologi Penelitian Kualitatif, Bandung PT. Remaja Rosda Karya

Muflihin, Kusdar. 2003. Penanaman Nilai-Nilai Agama Dalam Manajemen Pendidikan (Studi Kasus Di SD Muhammadiyah 1 Samarinda Kalimantan Timur) Tesis Program Pascasarjana UMM Malang.

Muhaimin, 2001, Paradigma Pendidikan Islam. Bandung : PT Remaja Rosda Karya - 2005. Pengembangan Kurikulum Pendidikan Agama Islam. Jakarta : RajaGrafindo Persada

-2008, Rekonstruksi Pendidikan Islam. Jakarta: RajaGrapindo Persada

--------------, 2009, Pengembangan Kurikulum Pendidikan Agama Islam Di Sekolah, Madrasah, dan Perguruan Tinggi. Jakarta : PT RajaGrapindo Persada . et al . 2007. Kawasan dan Wawasan Studi Islam. Jakarta Prenada Media .2006, Nuansa Baru Pendidikan Islam, Mengurai Benang Kusut Pendidikan Islam. Jakarta: RajaGrapindo Persada

Muhajir, Noeng. 2003. Metode Penelitian Kualitatif. Yogyakarta : Kare Sarasin.

Mulyasa. 2007. Menjadi Kepala Sekolah Profesional. Bandung : Remaja Rosdakarya

Nawawi, Hadari. 2003. Kepemimpinan Dalam Mengefektifkan Organisasi. Yogyakarta: Gajahmada University 
RAUDHAH Proud To Be Professionals qurnal Tarbiyakndamiyah

Volume 3 Nomor 1 Edisi Juni 2018

P-ISSN : 2541-3686

Nasih, Ahmad Munjih \& Nurkholidah Lilik. 2009. Metode dan Teknik Pembelajaran Pendidikan Agama Islam. Bandung: Refika Aditama

Nazir, Moh. 2003. Metode Penelitian. Jakarta : Ghalia Indonesia

Pahlawan Kayo, Khatib. 2005. Kepemimpinan Islam dan Dakwah. Jakarta : Amzah

Poloma, Margaret. 1994. Sosiologi Kontemporer, terj. Jakarta: Rajawali Perss

Qomar, Mujammil. 2007. Manajemen Pendidikan Islam. Jakarta: Air Langga.

Rosyada, Dede. 2007. Paradigma Pendidikan Demokratis, Sebuah model Pelibatan Masyarakat dalam Penyelenggaraan Pendidikan. Jakarta: Prenada Media Group.

Sa'id, Mas'ud. 2007. Kepemimpinan, Pengembangan Organisasi Team Building E Prilaku Inovatif. Malang: UIN Press.

Satori, Djam'an \& Aan Komariah, Mei 2009. Metode Penelitian Kualitatif. Bandung: Alfabeta

Sugiono, April 2009, Metode Penelitian Pendidikan: Pendekatan Kuantitatif, Kualitatif dan $R \mathcal{E D}$ ( research and development), Bandung Alfabeta

Sukardi, 2007, Metode Penelitian Pendidikan Kompetensi dan Praktiknya, Jakarta : Bumi Aksara.

Suprayogo, Imam. 1999. Reformasi Visi dan Misi Pendidikan Islam. Malang: STAIN Press

Soelaeman, MI. 1998. Manusia Religi dan Pendidikan. Jakarta: Dirjen PTPLPTK

Sondang P, Siagian. 1982. Filsafat Administrasi. Jakarta: Gunung Agung

Tasmara, Toto. 2006. Spiritual Centered Leadership: Kepemimpinan Berbasis Spiritual. Jakarta: Gema Insani

Undang-Undang RI No 20 Tahun 2003 Tentang Sisdiknas E Peraturan Pemerintah RI No 47 Tahun 2008. Bandung: Citra Umbara

Usman, Husaini. 2008. Manajemen Teori Praktek \& Riset Pendidikan. Jakarta: Bumi Aksara

Veitzal ,Rifai. 2003. Kepemimpinan Dalam Mengaktifkan Organisasi. Yogjakarta: Gajahmada, University

Wahidmurni, 2008. Cara Mudah Menulis Proposal dan Laporan Penelitian Lapangan . Malang : UM Press

Wahjosumidjo, 1999. Kepemimpinan Kepala Sekolah, tinjauan teoritik dan permasalahannya. Jakarta : Raja Grapindo Persada 
Kepemimpinan Kepala Sekolah Dalam Mengembangkan Budaya Agama Di Mtsn 01 Ogan Ilir

Moh. Fuadi

Wahyudi. 2009. Kepemimpinan Kepala Sekolah Dalam Organisasi Pembelajaran. Bandung: Alfabeta

Zaini, Syahminan. 1980. Mengenal Manusia Lewat Al-Qur'an. Surabaya : Bina Ilmu

Zamroni, 2007, Sistem Nilai Dalam Kultur Organisasi Perguruan Tinggi Islam (Studi Kasus Pada UIN Malang) Program Pascasarjana UIN Malang. 